\title{
Sometimes, when we talk about Damaged Buildings- it can be controversial
}

\author{
Talal Awwad ${ }^{1,2^{*}}$, Vladimir Ulitsky $^{3}$ and Alexey Shashkin ${ }^{4}$ \\ ${ }^{1}$ L.N.Gumilyov Eurasian National University, Astana, Kazakhstan \\ ${ }^{2}$ Damascus University, Syria \\ ${ }^{3}$ Emperor Alexander I St. Petersburg State Transport University, 9 Moskovsky, 190031, St. Petersburg, \\ Russia \\ ${ }^{4}$ Institute Georeconstruction, St. Petersburg, Russia
}

\begin{abstract}
The entire civilized world follows the state of unique monuments of the east, including Syria, where military operations are not yet over. Separate monuments of antiquity have been destroyed, which require immediate examination and, at a minimum, preventing structural elements from collapse. Naturally, publications of the time of the Second World War (Russia, Japan, Poland...) most fully represented the world restoration practice of destruction from mass bombardments and shelling. For these works, it is possible to systematize the degree of danger of the state of the objects at the time of their possible restoration and to estimate the damage caused by the enlarged parameters. Unfortunately, today, the revision of this practice, taking into account modern technologies of engineering restoration of damaged and reconstructing lost monuments, becomes urgent. Without this, it is impossible to defeat the vandals of the 21 st century.
\end{abstract}

\section{Introduction}

Syrian Arab Republic is located on the west wing of the Fertile Crescent in an important location between the East and the West. Syria has seen some of the oldest and most important civilizations as evidenced by the enormous archaeological discoveries, which some of them dates back to over 8,000 years BC. In Syria there are more than 4,500 archaeological site dated back to different periods of history. Archaeologists consider Syria the center of one of the oldest civilizations on earth, wherein was the beginning of human settlement, the first urban planning and development of the alphabet. In Syria were the first cities in history, such as the ancient kingdom of Ebla, from 2500 to 2400 BC ,the Kingdom of Mary about 2900 $\mathrm{BC}$ and Palmyra which flourished in the second half of the first century BC. Throughout the Syrian six years' war, many of Syrian historical monuments have been completely or particularly destroyed brought collapse our human history. Maintaining the remain monuments would be the prior task for engineers to conserve the historical heritage of Syria to ensure our identity preservation. In order to achieve that, we should deal with each

*Corresponding author: dr.awwad.gfce@gmail.com 
historical building on its own taking in account the soil and foundation type, historical character and the function.

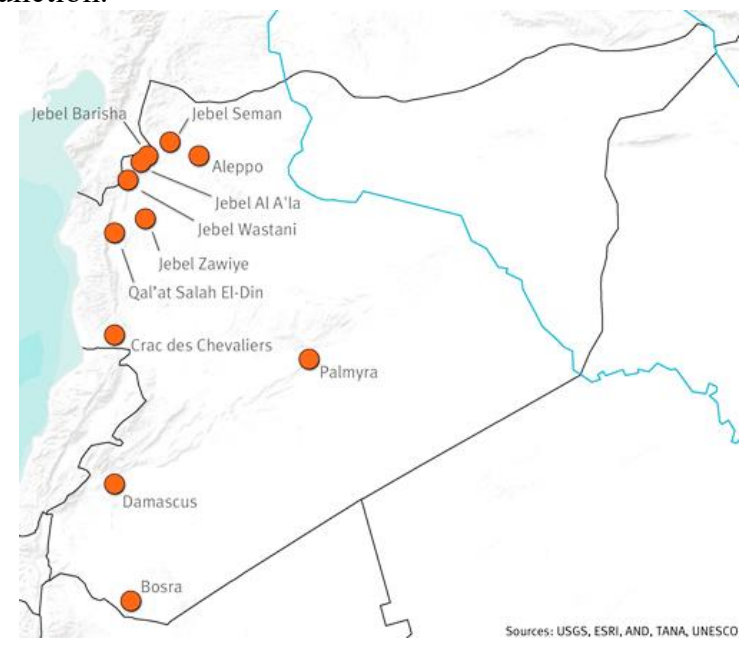

Fig. 1. Overview of Syrian World Heritage sites.

This paper will present two of the historical buildings in Syria; Suleiman Tikie located in Damascus city and Maarat al-Numan Museum located in Idlib city. The two buildings have been subjected to different degrees of damage due to current military actions as well as time effects.

\section{Suleiman Tikie}

Tikies are important religious tradition buildings dating back to Ottoman era and were used as a place for worship and helping the passers-by. Suleiman Tikie is located in Al-marjeh Area-Damascus. It consists of eastern and western buildings designed according to Ottoman architecture style [1]. Walls were built with thickness of $1 \mathrm{~m}$ to keep moderate temperature inside the building. Wood was used to make columns with crowns holed roofs. Materials used in the building were wage and gypsum. Ground was furnished by small square wage $(20 * 20 * 4) \mathrm{cm}[2]$

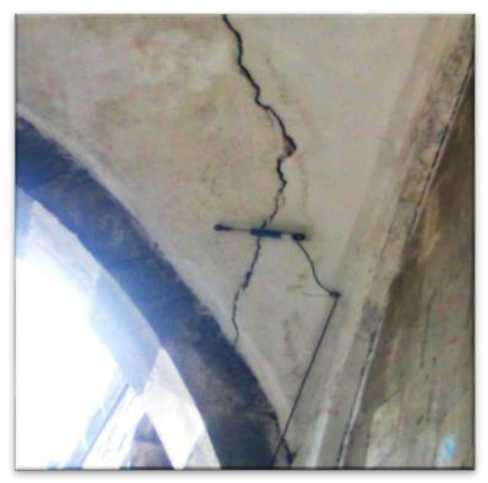

Fig. 2. Cracks in the cupolas of Suleiman Tikie.

Cracks appearance were observed in walls and cupolas. After 3 years of detecting the vertical movements: the maximum settlement was $2.44 \mathrm{~mm}$ and the minimum was $0.5 \mathrm{~mm}$. Furthermore, it appears corrugation in the soil surface in the courtyard $[3,4]$. Many methods 
could be used to improve and support foundations but the usage of modern material which are different from the original foundation materials has disadvantages. Therefore, this paper will discuss the use of lime because of its neutrality which won't effects the historical mission of the building. It should be mentioned that many mortar shells have been fallen around the location of Suleiman Tikie in AL-marjeh and more investigations should be made to detect the damages on both foundations and building structure which made the waves appearance in the courtyard even worse.

\subsection{Methods of soil improvement}

Current methods of foundation restoration depend on soil improvement under the historical building foundations by cement mortar injection, or foundation supporting by micro piles, and using concert or metal beams under the foundation.

Both mentioned ways of soil improvement and foundation support have disadvantage of using modern material such as metal and concrete, which is not natural and different from the original foundation materials, therefore we recommend soil improvement by lime, because it is natural material and doesn't detract the building 's historical character

\subsection{Suggested method of Soil improvement with lime (lime stabilization)}

The foundations of Suleiman Tikie are based on a clay soil which made the lime is an excellent choice because it can modify almost all fine-grained soils. Lime decreases the plasticity index, increases the workability and shrinkage limit, reduces shrinkage cracking, eliminates almost all swelling problems, increases the California Bearing Ratio (CBR) and soil strength, as well as increases permeability of soils [5]. Soil improvement method by lime is an effective way to deal with the historical building damage as lime is a natural and not differ from the original foundation materials.

Lime is an excellent choice for short-term modification of soil, and it can modify almost all fine-grained soils, but the most dramatic improvement occurs in clay soils of moderate to high plasticity. Modification occurs because calcium cations supplied by the hydrated lime replace the cations normally present on the surface of the clay mineral, promoted by the high $\mathrm{pH}$ environment of the lime-water system. Thus, the clay surface mineralogy is altered, producing the following benefits:

- Plasticity reduction

- Reduction in moisture-holding capacity (drying)

- Swell reduction

- Improved stability

In this paper, soil improvement techniques with lime is recommended for restoration of historical building foundations because It is very useful and efficient to improve and stabilize the soil under and surround the foundation without harming its historical characteristics.

Deep soil improvement with lime can be divided into two main types, deep column mixing method and the method of drill hole lime pile or chemical lime pile. Regarding deep column mixing method, lime is injected into the soil by pressure, and mixed with it along the column hole in order to form a lime column, which support the structure with its increased strength. Furthermore, the lime effect spreads in the soil around the lime column increasing the soil strength and decreasing its swelling characteristics.

Regarding to drill hole lime pile (chemical lime pile) [6], This technique consists of holes in the ground filled with lime, and it is constructed in situ by using a giant auger, the auger is drilled into the soil to the required depth, the direction of rotation is reversed, and the auger is slowly withdrawn. As the auger is withdrawn, powdered quicklime is pneumatically pumped into the soil, it can be constructed using the quick lime in a slurry form or powder 
form [7]. In the field application, a hollow tube is Pushed into the soil to the required depth and quicklime is then forced into the pile by air pressure as the tube was withdrawn.

Stabilization process provided by the lime pile is controlled mainly by the lime migration, the radius of effective distance of lime migration depends on many factors such as type of soil ,soil moisture, soil permeability .Some references stated that, there is a linear relationship between $(\mathrm{R})$ the radius of effective distance of lime migration, and $(\mathrm{D})$ the lime pile diameter $(\mathrm{R}=2.53 \mathrm{D}+2.07) \mathrm{cm}$, while other references stated that lime migration could penetrate into soil up to 5D in radial direction[8]. But this topic needs further in-depth studies; it is currently under study through field and laboratory experiments. The lime pile should be constructed before the rainy season in order to allow ion migration from the column into the soil.

Installation of drill hole lime pile in the soil can improve the soil strength surround the lime pile in both vertical and radial directions. The higher strength attained will be near the lime pile and decreased gradually with the distance from it.

\section{Maarat Al-Numan Museum}

It is a mosaics museum from the Dead Cities located in Maarat al-Numan city which also known as al-Ma arra. This city in north-western Syria is located at the highway between Aleppo and Hama near the Dead Cities of Bara and Serjilla. The museum was built from huge lime stones. The building consists of a wide opened heavenly courtyard with Tikie in the middle. Unfortunately, a huge part of the museum has been destroyed by the recent war. Walls and foundations need supporting in order to rebuild this historical museum.

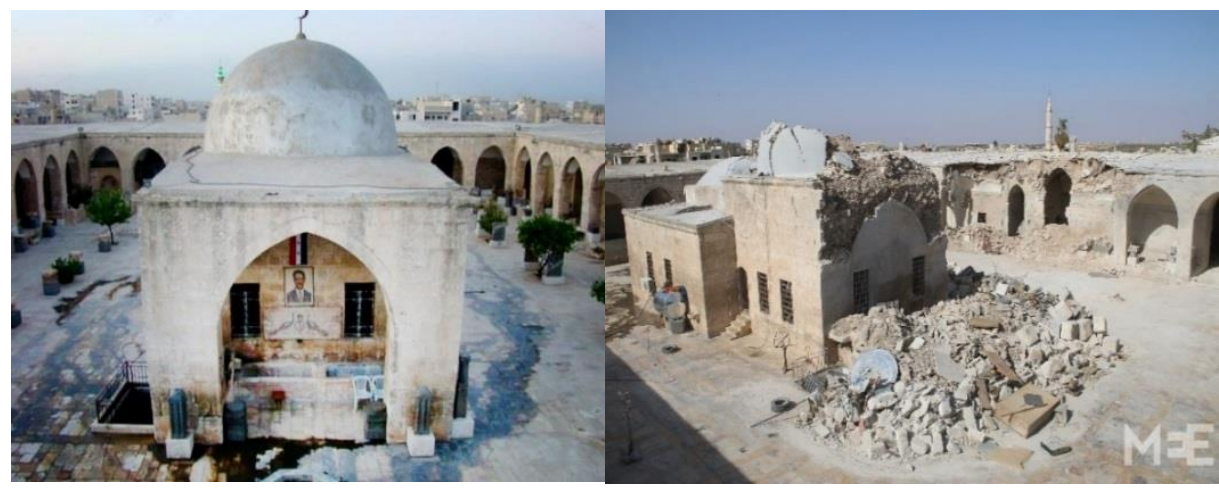

Fig. 3. Maarat al-Numan Museum (before - after).

\subsection{Foundations restoring}

Maarat al-Numan museum foundations are the same of any historical buildings made of stone. The museum as we mentioned before subject to a rough military strikes and explosions leaded to effect the building as well as the foundations. Foundations material used was broken wage and lime with ash as mortar and when the foundations experienced an explosion, it quickly discloses bulging, bowing, shifting and settlement. From the current situation of the museum, most of the foundations facing a failure problem as huge stones have already failed and cracks appeared in the remain parts. Strengthen the foundations can be achieved by increasing their width using local and natural materials, construct pile foundations under the building to support the foundations, micro piles, using concrete or metal beams under foundations. 


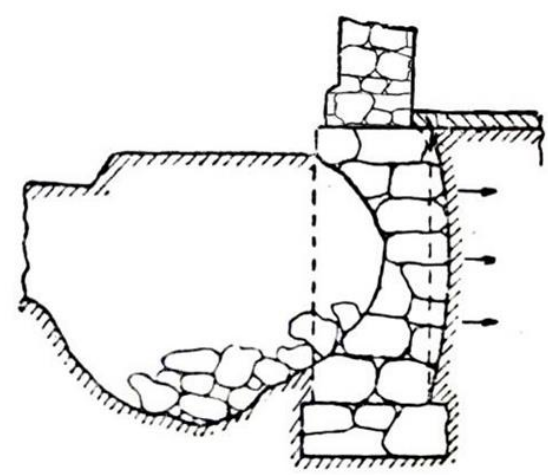

Fig. 4. Destruction of strip foundations within the explosion.

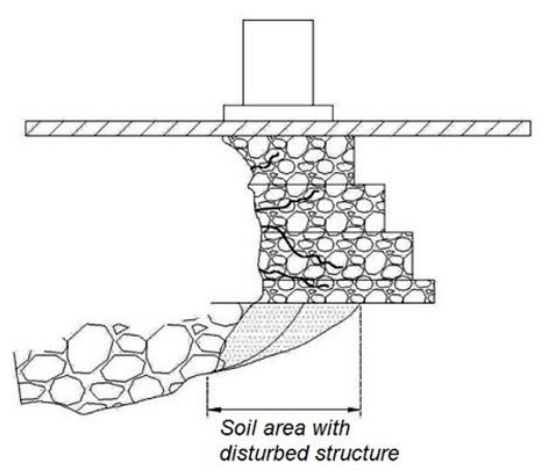

Fig. 5. Destruction of Foundations under columns within the explosion.

\section{Discussion}

Sometimes, when we talk about Damaged Buildings- it can be controversial. There are two approaches when restoring historical Monuments:

1. The Venice Charter: The general direction is conservation of monuments (preservation in the existing form)

2. Soviet Restoration School: the restoration of the monument for a certain period on the basis of scientific research.

We do not decide in this paper which approach is correct. This is the business of specialists - art historians, archaeologists and restorers. But if after the Second World War in the Soviet Union the conservation approach would have triumphed - the suburbs of Leningrad would have become a monument of fascist vandalism.

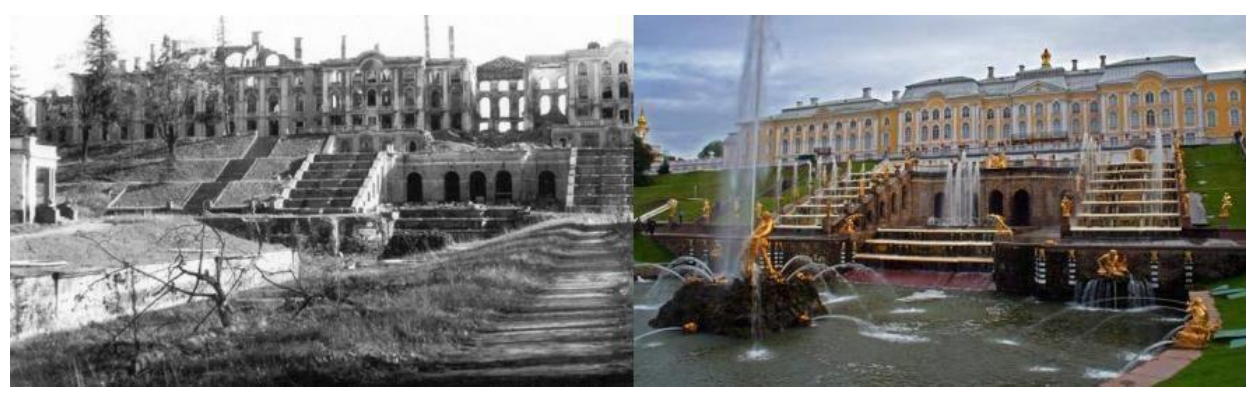

Fig. 6. Peterhof Palace, Peterhof, Saint Petersburg, Russia.

\section{Conclusion}

The war did not only kill people but also has been the reason of the loss of non-replaceable historical monuments. Each historical building in Syria has its own character and richness and when the work for restoring theses heritage starts, we should deal with each case separately. Improving the soil and supporting the foundations should take these following steps; a full architecture study for the building, geological and geotechnical surveys, historical study and constant consultant support to choose the best method for restoring the building without changing its task or character. Using lime injection method to improve the 
soil considered one of the important way to support and strengthing without harming the historical value.

Sometimes, when we talk about Damaged Buildings- it can be controversial. Therefore, we should seek a compromise between approaches of conservation and a scientific restoration of historical monuments.

\section{References}

1. Study of Suleiman Tikie restoration and maintenance project, Ministry religious issues (Mosques and Churches) (Syria, 2008)

2. E. Al-Taie, N. Al-Ansari, S. Knutsson, Journal of Earth Sciences and Geotechnical Engineering 2, 39-49 (2012)

3. T. Awwad, Proceedings of Workshop ATC19, 18th ICSMGE 18th ICSMGE World Congress, 89-94 (2013)

4. T. Awwad, Proceedings of the Eighth Asian Young Geotechnical Engineering Conference, 21-27 (2016)

5. M.H. Ghobadi, Y. Abdilor, R. Babazadeh, Bulletin of Engineering Geology and the Environment 73-2, 611-619 (2014)

6. A.A. Al-Rawas, M.F.A. Goosen, Expansive soils Recent advances in characterization and treatment (2006)

7. P.K. Wong, Ground improvement case studies chemical lime piles and dynamic replacement (Malaysia and Egypt, 2001)

8. A. Muntohar, J.-L. Hung, Strength distribution of soft clay surround lime-column (Chan \& Law, Taylor and Francis Group, London, 2007) 